$\stackrel{\odot}{||}$

\title{
DYNAMIKA WŁADZY W POWOJENNYCH CHINACH. PRÓBA ANALIZY TEORETYCZNEJ
}

ABSTRACT. Dawid Rogacz, Dynamika władzy w powojennych Chinach. Próba analizy teoretycznej [Dynamics of Power in Post-war China. An Attempt of Theoretical Analysis], edited by K. Brzechczyn "Człowiek i Społeczeństwo" vol. XLII: Modelowanie świata społecznego. Założenia - rekonstrukcje analizy [On Modeling of Social World: Assumptions - Reconstructions - Analysis], Poznań 2016, pp. 161-181, Adam Mickiewicz University Press. ISSN 0239-3271.

The aim of this paper is to make an attempt to analyze the dynamics of thr political power in People's Republic of China, using the conceptual apparatus of Leszek Nowak's non-Marxian historical materialism. By means of application of his first model of the dynamics of power, I am going to generalize in theoretical manner main political changes in post-war China: from foundation of PRC, through Cultural Revolution and Opening Reforms up to the Chinese politics after 1989. Conducted analysis will allow me to make three wide-ranging predictiions concerning further development of China in the field of politics, economy and ideology.

Dawid Rogacz, Instytut Filozofii UAM, ul. Szamarzewskiego 89c, 61-568 Poznań, Poland, e-mail: dawid.rogacz@amu.edu.pl

\section{Wprowadzenie}

Celem niniejszego artykułu jest analiza teoretyczna dynamiki władzy politycznej w społeczeństwie chińskim z wykorzystaniem aparatury pojęciowej nie-Marksowskiego materializmu historycznego, koncepcji stworzonej przez Leszka Nowaka, współtwórcę poznańskiej szkoły metodologicznej. Poprzez aplikację opracowanej przez Nowaka teorii władzy, ściślej rzecz biorąc, modelu I, zamierzam dokonać interpretacji przemian politycznych, gospodarczych i ideologicznych w powojennych Chinach. 
Dominującym rysem analiz dziejów oraz przemian gospodarczych w Chinach jest ich rozdwojenie na okres przed i po reformach otwarcia (改革开放, găigé kāifàng). Reformy Deng Xiaopinga z 1978 r. traktowane są jako porzucenie radykalnych projektów Mao oraz przejęcie zachodnich wzorców kapitalistycznych przy zachowaniu komunistycznych pozorów. Przyjmowanie tak skrajnej nieciągłości w rozwoju historycznym powojennych Chin nie koresponduje ze standardami nauk społecznych, które zobowiązane są do poszukiwania praw możliwie najogólniejszych, opisujących zarówno w wymiarze synchronicznym, jak i diachronicznym strukturę społeczeństw ludzkich, nie wspominając już o ostatecznie porzuconych ambicjach prognozowania fenomenów społecznych. W niniejszym artykule postaram się mimo to dokonać analizy teoretycznej dynamiki władzy w powojennych Chinach oraz wysunąć kilka prognoz politycznych wynikających z przyjętych założeń.

Rzekomo nagłe przejście od maoizmu do (ze wstydem skrywanego) kapitalizmu sugeruje klucz ideologiczny jako punkt wyjścia czynionych analiz. Przeczy mu jednak już sama instrumentalność, z jaką chińscy politycy posługują się nomenklaturą komunistyczną. Rezultatem świadomości tego faktu, przy jednoczesnej niemożności odrzucenia klucza ideologicznego, stała się moda na ukazywanie przemian 1978 r. jako wynikających z „ducha” konfucjanizmu, przez analogię do słynnych analiz Maxa Webera dotyczących wpływu etyki protestanckiej na powstanie kapitalizmu. Pomija się jednak w takim ujęciu fakt, że po rewolucji kulturalnej wpływ konfucjanizmu na sferę publiczną i motywacje działań polityków był znikomy, a ponowne zawitanie elementów nauk konfucjańskich do treści wystąpień przewodniczących ChRL datuje się dopiero na początek XXI wieku¹. Sam konfucjanizm nie był też nigdy historycznie motorem zmian ekonomicznych zmierzających w stronę kapitalizmu, choć miał dwa tysiąclecia, by tego dokonać - jeszcze w XVII wieku Yan Yuan proponuje reformę społeczną, mającą polegać na powrocie do systemu studnia-pole z czasów dynastii Zhou (XI-VIII wiek p.n.e. $)^{2}$. W praktyce próby ukazania wkładu konfucjanizmu w powstanie chińskiej odmiany kapitalizmu traktują nie tyle o konfucjanizmie per se, ile o jego współczesnym, mocno synkretycznym wariancie, powstałym pod wpływem polemik z marksizmem, filozofią zachodnią oraz myślą chrześcijańskąa.

${ }^{1}$ D. Bell, China's New Confucianism: Politics and Everyday Life in Changing Society, Princeton University Press, Princeton 2010, ss. 3-18.

${ }^{2}$ F. Avanzini, Religie Chin, tłum. K. Stopa, WAM, Kraków 2004, s. 115.

3 J. Makeham, New Confucianism. A Critical Examination, Palgrave MacMillan, New York 2003, ss. 16-17. 
Możliwości systemowej analizy przemian politycznych w powojennych Chinach, bez odwoływania się w pierwszym rzędzie do świadomości społecznej, lecz do samej dynamiki władzy politycznej (dysponującej środkami przymusu) wyznaczanej sprzecznościami interesów między klasą władców a klasą obywatelską, dostarcza właśnie teoria władzy w nie-Marksowskim materializmie historycznym (dalej: n-Mmh). Pragnie on również w teoretyczny sposób ująć zmiany, jakim podlega stosunek władzy do społeczeństwa obywatelskiego, stąd obecnych w tej teorii modeli nie sposób traktować jako zwykłych uproszczeń złożonych procesów czy rektyfikacji przyjętych założeń. Leżąca u podstaw n-Mmh idealizacyjna teoria nauki wyklucza takie interpretacje teorii społecznej Nowaka, dostarczając całej koncepcji terminologicznej precyzji, a co za tym idzie - jasnych kryteriów jej aplikacji do poszczególnych przypadków empirycznych.

W pierwszej części artykułu przedstawię podstawowe założenia n-Mmh, zwłaszcza modelu I teorii władzy. Następnie dokonam historycznej operacjonalizacji modelu I oraz przedstawię prognozy dotyczące dalszych przemian politycznych w Chinach, wynikające z założonego modelu oraz całej koncepcji.

\section{Podstawowe założenia nie-Marksowskiego materializmu historycznego}

Podstawowym założeniem n-Mmh jest wyszczególnienie w ramach każdego społeczeństwa trzech sfer: ekonomicznej, politycznej oraz kultury. W obrębie każdej z tych sfer tworzone są wewnątrzspołeczne podziały, wynikające z dysponowania pewnym rodzajem sił materialnych. Dysponowanie siłami materialnymi produkcji wyznacza podział społeczeństwa na właścicieli oraz bezpośrednich producentów. Dysponowanie siłami materialnymi przymusu stanowi natomiast podstawę podziału na władców i społeczeństwo obywatelskie. Dysponowanie środkami materialnymi indoktrynacji dzieli zaś społeczeństwo na kapłanów i wiernych. W ramach każdego z wymienionych podziałów interesy grup są ze sobą sprzeczne, są to więc podziały o charakterze klasowym ${ }^{4}$. Waldemar Czajkowski wskazuje na pięć cech odróżniających n-Mmh od materializmu historycznego Marksa w kanonicznej interpretacji Langego:

${ }^{4}$ L. Nowak, U podstaw teorii socjalizmu, t. 1: Własność i władza. O konieczności socjalizmu, Nakom, Poznań 1991, ss. 176-177. 
- podstawowym źródłem dynamiki historycznej nie jest, jak u Marksa, rozwój sił wytwórczych, lecz konflikty pomiędzy klasami społecznymi;

- polityka i kultura nie są „nadbudową” gospodarki, lecz niezależnymi od niej sferami;

- zamiast dwóch głównych klas, wyznaczonych przez dysponowanie środkami produkcji, mamy trzy podziały klasowe, które mogą się ponadto krzyżować lub nakładać na siebie, co komplikuje obraz struktury społecznej;

- istotna jest nie tylko walka międzyklasowa, ale i wewnętrzklasowa, tj. konkurencja pomiędzy członkami klasy panującej;

- u podstaw filozofii historii Nowaka leży jasno określona antropologia filozoficzna, tj. nie-Ewangeliczny model człowieka ${ }^{5}$.

Dana klasa społeczna może, jak wspomniano, dysponować jednocześnie więcej niż jednym rodzajem sił materialnych - stąd w n-Mmh rozróżnia się społeczeństwa klasowe i supraklasowe. W społeczeństwach klasowych istnieją trzy oddzielne klasy dominujące: władcy, właściciele oraz kapłani. Jedna z tych klas zazwyczaj dominuje nad pozostałymi, dlatego wyróżnia się trzy odmiany społeczeństw: ekonomiczne, polityczne oraz hierokratyczne. W społeczeństwach supraklasowych dochodzi natomiast do połączenia w ramach jednej klasy społecznej dyspozycji nad dwoma lub trzema materialnymi środkami społecznymi. Można zatem kombinatorycznie wyróżnić klasę władców-właścicieli, władców-kapłanów czy właścicieli-kapłanów ${ }^{6}$. W granicznym przypadku środki przymusu, produkcji oraz indoktrynacji kumulowane są w rękach jednej potrójnej klasy. Tym granicznym przypadkiem jest społeczeństwo socjalistyczne?

W teorii władzy w n-Mmh przyjmuje się szereg założeń idealizujących, które pozwalają w rezultacie (1) skonstruować ogólny model struktury i dynamiki władzy oraz (2) na drodze stopniowych konkretyzacji, tj. znoszenia założeń idealizujących, zastosować modele władzy do coraz bardziej złożonej rzeczywistości politycznej (i historycznej). Procedura ta doprowadziła

${ }^{5}$ W. Czajkowski, Kilka uwag o Leszka Nowaka nie-Marksowskim materializmie historycznym oraz Immanuela Wallersteina i Andre G. Franka teoriach systemu światowego, „Poznańskie Studia z Filozofii Humanistyki” t. 22: Jednostka w układzie społecznym. Próba teoretycznej konceptualizacji, red. K. Brzechczyn, M. Ciesielski, E. Karczyńska, Wyd. Naukowe WNS UAM, Poznań 2013, ss. 196-197.

${ }^{6}$ Wyjściowa typologia społeczeństw w nie-Mmh zbudowana przez Leszka Nowaka była wielokrotnie rozbudowywana. Zob. K. Brzechczyn, O wielości linii rozwojowych..., ss. 73-86; M. Ciesielski, Problem kumulacji podziałów klasowych we współczesnym kapitalizmie, „Poznańskie Studia z Filozofii Humanistyki” t. 22, ss. 131-152; T. Zarębski, Problem totalitaryzacji kapitalizmu, „Poznańskie Studia z Filozofii Humanistyki” t. 19: Ścieżki transformacji, red. K. Brzechczyn, Zysk i S-ka, Poznań 2003, ss. 229-260.

${ }^{7}$ L. Nowak, U podstaw teorii socjalizmu, t. 1, ss. 178-180. 
Nowaka do analizy ewolucji teorii władzy ujętej w ramach ośmiu modeli. U ich podstaw leżą określone założenia statyczne i dynamiczne. Główne założenie statyczne to przesłanka, że każdy władca maksymalizuje sferę kontroli nad działaniami obywateli, podczas gdy w interesie społeczeństwa obywatelskiego leży wzrost autonomii obywatelskiej. Władcy, którzy tego nie czynią, są „eliminowani” przez polityczną konkurencję. Sfera indywidualnych działań będących poza kontrolą władców stanowi sferę autonomii obywatelskiej w opozycji do sfery regulacji. Stosunek sfery regulacji do sumy wszystkich działań społecznych określa obywatelską alienację. Opór obywatelski zależy od poziomu alienacji obywatelskiej. Relację tę charakteryzuje się następująco:

- dla niskich poziomów alienacji obywatelskiej opór obywatelski jest również niski - buntują się wyłącznie społeczne marginesy (obszar pokoju klasowego);

- dla średnich poziomów alienacji obywatelskiej opór społeczny osiąga swoje maksimum (obszar rewolucji pierwszego rodzaju);

- gdy poziom alienacji obywatelskiej wzrasta jeszcze bardziej, poziom oporu obywatelskiego znacznie spada (obszar zniewolenia) ${ }^{9}$.

Innym założeniem statycznym teorii władzy jest teza o rewaloryzacji autonomicznych więzi społecznych. Gdy poziom kontroli politycznej przekroczy pewien próg, ludzie dążą do zastąpienia (lub obchodzenia) zetatyzowanych form życia zbiorowego poprzez więzi nawiązane bezpośrednio, poza władzą i w ramach autonomicznych struktur społecznych. Powyższe założenia statyczne mają charakter bezczasowy.

W modelu I przyjmuje się ponadto szereg założeń idealizujących:

- społeczeństwo istnieje w stanie całkowitej izolacji - nie podlega żadnym wpływom zewnętrznym;

- społeczeństwo jest czysto polityczne, tj. istnieją w nim jedynie dwie klasy: władców i obywateli (tj. dysponujących i niedysponujących środkami przymusu), bez żadnych instytucji politycznych, politycznych doktryn itd.;

- technologia pozostaje na stałym poziomie, nie dokonuje się postęp techniczny;

- władcy bezpośrednio, tj. bez pośrednictwa służb specjalnych, posługują się środkami przymusu;

${ }^{8} \mathrm{~W}$ interesie właścicieli leży maksymalizacja produktu dodatkowego, zaś w interesie bezpośrednich producentów - powiększanie kapitału zmiennego. W interesie kapłanów leży natomiast zdominowanie zasobu idei wyznawanych przez wiernych, a w interesie wiernych - wolność wewnętrzna.

${ }^{9}$ L. Nowak, U podstaw teorii socjalizmu, t. 3: Dynamika władzy. O strukturze i konieczności zaniku socjalizmu, Nakom, Poznań 1991, ss. 64-66. 
- nie występuje organizacja państwowa, a zwłaszcza hierarchia władzy;

- świadomość klasowa nie wpływa na społeczne myślenie danych członków klasy.

W modelu I (wariant bezpętlowy) wyróżnia się następujące fazy rozwoju politycznego: fazę postępującej alienacji obywatelskiej, fazę rewolucji obywatelskiej, fazę zniewolenia z subfazą samozniewolenia władzy, fazę cyklicznych deklasacji i fazę cyklicznych rewolucji.

W fazie postępującej alienacji obywatelskiej poziom regulacji władczej jest niewielki. Mechanizm konkurencji politycznej zmusza typowego władcę do poszerzania sfery wpływu. W rezultacie poziom regulacji w społeczeństwie jako całości systematycznie wzrasta, przyczyniając się do stałego zwiększania poziomu alienacji obywatelskiej. Po pewnym czasie społeczeństwo wchodzi w fazę rewolucji obywatelskiej. Rezultatem tego procesu może być stłumienie rewolucji lub zwycięstwo obywateli, secundum non datur ${ }^{10}$. Przegrana rewolucji prowadzi do fazy zniewolenia, w której upowszechnia się porewolucyjny terror. Jego rezultatem jest zniszczenie autonomicznych relacji społecznych poprzez eliminację najbardziej aktywnych społecznie obywateli. Taki rozkład społeczeństwa obywatelskiego skutkuje deklasacją obywateli.

Drugim możliwym wynikiem jest zwycięstwo obywateli, które okazuje się w praktyce zwycięstwem rewolucjonistów. Ustanawiają oni nową elitę władzy, dysponując środkami przymusu wobec rewolucyjnych mas. Rewolucyjna elita stanowi zalążek nowej klasy władców - z perspektywy n-Mmh rewolucja, choć w nazwie „obywatelska”, stanowi jedynie zastąpienie starej klasy władców nową. Mechanizm konkurencji politycznej prowadzi do konfliktu wśród rewolucjonistów - rewolucjoniści, którzy sprzeciwiają się przeistoczeniu rewolucyjnych elit w klasę władców politycznych, są odsunięci od władzy, a nierzadko i życia. Wskutek wystarczającego zniewolenia mas nowo powstała klasa władców przystępuje do poszerzenia sfery regulacji w obrębie samej klasy władców - ma miejsce faza zniewolenia z subfazą samozniewolenia władzy. Po czystkach następuje dalsze poszerzanie sfery regulacji, które przekracza próg krytyczny, powodując tzw. przebudzenie obywatelskie. Następuje nowa rewolucja ${ }^{11}$, która inicjuje fazę cyklicznych deklasacji.

${ }^{10}$ Tylko modelu I. Konkretyzację tej części rozwoju politycznego omawia: K. Brzechczyn, Zapaść obywatelska i absorpcja elit. Próba poszerzenia teorii ewolucji społeczeństwa politycznego, „Poznańskie Studia z Filozofii Humanistyki” t. 17: Marksizm, liberalizm, próby wyjścia, red. L. Nowak, P. Przybysz, Zysk i S-ka, Poznań 1997, ss. 399-404.

${ }^{11}$ L. Nowak, U podstaw teorii socjalizmu, t. 3, ss. 87-92. 
W przeciwieństwie do rewolucji pierwszego rodzaju, przegrana w rewolucji drugiego rodzaju nie skutkuje terrorem, lecz ustępstwami ze strony władzy. Sfera regulacji władczej maleje, a rośnie sfera autonomii społecznej, co wywołuje kolejne rewolucje. Każda taka rewolucja jest więc bardziej masowa od poprzedniej. Tak długo, jak są to rewolucje przegrane (wygrana, przynosząc pętlę obywatelską, wróciłaby nas do początku sekwencji faz), cykl deklasacji trwa. Jak pisze Leszek Nowak:

Proces cykliczny „rewolucja - zwycięska kontrrewolucja - koncesje - etatystyczny napór - rewolucja itd.” trwa tak długo, dopóki nie dojdzie do rewolucji prawdziwie masowej, w której angażuje się tak wielka liczba obywateli, że masowa akcja represyjna staje się niewykonalna i władza musi od razu pójść na koncesje ${ }^{12}$.

W końcu dochodzi do rewolucji tak masowej, że władza zamiast represji zmuszona jest rozpocząć od koncesji. W fazie cyklicznych rewolucji kolejne ustępstwa w coraz większym stopniu redukują władzę do roli administratora życia publicznego. Konkurencja między władcami zmusza ich jednak do zwiększenia (odzyskania) sfery regulacji władczej; w rezultacie narastającej równolegle alienacji obywatelskiej następuje rewolucja. Masowość tej rewolucji oraz dominanta postaw rewolucyjnych wśród obywateli sprawia, że ani istniejąca, ani nowa (rewolucyjna) władza nie są jej w stanie spacyfikować. Pętle obywatelskie nie zanikają, a rewolucja obywatelska nie grozi powrotem do punktu wyjścia. W fazie pokoju klasowego poziom alienacji obywatelskiej utrzymuje się poniżej progu konfliktu klasowego.

Przedstawione modele Nowak odniósł do dynamiki władzy w Związku Radzieckim. Rewolucje: lutowa i październikowa stanowiły dwie kolejne pętle obywatelskie, tj. fazę pierwotnej rewolucji politycznej następującą po fazie postępującej alienacji obywatelskiej. W drugiej połowie lat 20. XX wieku dochodzi do deklasacji. Kolektywizacja oraz wzrost liczby więźniów Gułagu można interpretować jako fazę zniewolenia, zaś czystki - subfazę samozniewolenia władzy. Utrzymujące się zniewolenie owocowało rewolucją drugiego rodzaju, tj. falą strajków i powstań w Archipelagu Gułag, który doprowadził do likwidacji obozów i wymusił potępienie kultu jednostki. Następnie system wkroczył w fazę cyklicznych deklasacji: w latach 1959-1963 wojsko interweniuje w 14 strajkujących miastach ZSRR. Po tej fazie władza poszła na pewne ustępstwa i rozpoczęła się faza cyklicznych rewolucji. Fazę tę reprezentuje pierestrojka Gorbaczowa oraz likwidacja KPZR i ZSRR (1985-1991).

12 Ibidem, s. 93. 


\section{Historyczna operacjonalizacja modelu I teorii władzy. Ewolucja polityczna społeczeństwa chińskiego}

Zastosujmy przywołany model do interpretacji rozwoju politycznego społeczeństwa chińskiego ${ }^{13}$. Struktura społeczeństwa chińskiego może być interpretowana w kategoriach społeczeństwa trój-panowania klasowego. Oznacza to, iż klasa władców dysponuje trzema rodzajami środków panowania klasowego: przymusem, produkcją i indoktrynacją. Panowanie polityczne przejawia się w utrzymywanej od momentu powstania ChRL monopartyjności: Komunistyczna Partia Chin odgrywa przewodnią rolę w socjalistycznym państwie. W szczytowym okresie zniewolenia, tj. w 1975 r., kiedy uchwalono również nową konstytucję, zniesiono prokuraturę, niezawisłość sądów, prawo oskarżonego do obrony czy równość wobec prawa. Zarządzane i kontrolowane przez Partię komitety rewolucyjne i komuny ludowe utrzymywały sferę regulacji klasy władców na „dołach” społecznych. Współcześnie prawa te są szanowane, jednak w takim zakresie, w jakim nie zagrażają monopolowi klasy władców. We wzorowanych na Gułagu obozach pracy (改, láogăi) więzieni i torturowani są więźniowie polityczni, którzy trafili tam bez procesu sądowego ${ }^{14}$. Raport Amnesty International (za 2009 rok) podaje, że w Chinach łamie się większość praw człowieka, w tym prawo do stowarzyszania się. Hierarchia władzy w społeczeństwie chińskim jest zarazem hierarchią partyjną i państwową. Można w niej wyróżnić aparat władzy, elitę władzy i władcę najwyższego:

Sekretarz generalny jest najwyższym władcą, Politbiuro - elitą władzy, a Komitet Centralny - aparatem władzy. Aparat władzy stanowi 0,0005\%

${ }^{13}$ Nie-Marksowski materializm historyczny stosowany był do interpretacji historii społeczeństw pozaeuropejskich (np. K. Brzechczyn, O wielości linii rozwojowych w procesie historycznym. Próba interpretacji ewolucji społeczeństwa meksykańskiego, Wyd. Naukowe UAM, Poznań 2004; E. Karczyńska, Struktura społeczna Imperium Osmańskiego. Próba analizy teoretycznej, „Poznańskie Studia z Filozofii Humanistyki” t. 22, ss. 273290) bądź do interpretacji tekstów sakralnych powstałych w innych cywilizacjach (M. Bręgiel-Benedyk, Obraz struktury społecznej w Manusmryti. Próba analizy teoretycznej, „Poznańskie Studia z Filozofii Humanistyki” t. 22, ss. 291-319), bądź do parafrazy innych teorii opisujących rozwój społeczeństw pozaeuropejskich (T. Zarębski, Struktura klasowa społeczeństw hydraulicznych. Próba parafrazy teorii Karla Augusta Wittfogla w aparaturze pojęciowej nie-Marksowskiego materializmu historycznego, „Poznańskie Studia z Filozofii Humanistyki” t. 22, ss. 207-221).

${ }^{14}$ Informacje o obozach: Laogai Research Foundation, www.laogai.org [16.07.2016]. 
Tabela 1. Hierarchia władzy w Chinach

\begin{tabular}{|l|c|}
\hline \multicolumn{1}{|c|}{ Organ władzy politycznej } & Liczba członków \\
\hline Komunistyczna Partia Chin (KPCh) & 75000000 \\
Komitet Centralny KPCh & 376 \\
Biuro Polityczne KC KPCh & 25 \\
Sekretarz generalny KPCh & 1 \\
\hline
\end{tabular}

Partii, mimo iż członkami tej największej na świecie partii politycznej jest ok. $5 \%$ obywateli ${ }^{15}$.

Partia kontroluje również pozostałe sfery życia publicznego, tj. gospodarkę i kulturę, mając do wyłącznej dyspozycji środki produkcji i indoktrynacji. Własność prywatna została dopuszczona przez Partię w drodze kolejnych nowelizacji konstytucji, najpierw jako „uzupełnienie” (1988), a następnie jako „ważna część składowa” (1999) socjalistycznej gospodarki rynkowej. Zgodnie z obowiązującym prawem gospodarka ta podlega kontroli państwa (czyli Partii). Wszystkie zasoby naturalne, jak również grunty chińskie są własnością państwa - w Chinach nie można kupić ziemi, można ją tylko wydzierżawić16. Klasa władców niewątpliwie dysponuje więc środkami produkcji.

Podobnie rzecz się ma w sferze kulturowej. W czasie rewolucji kulturalnej poza dziełami Stalina i Hodży przestały ukazywać się zagraniczne książki, podjęto próbę zastąpienia opery pekińskiej operą rewolucyjną, a w latach 1967-1972 nie nakręcono nawet żadnego filmu fabularnego ${ }^{17}$. Młodzież, która nie uczęszczała w trakcie rewolucji do szkół, zmuszona była do uczenia się Czerwonej Ksiq̨żeczki Mao na pamięć. Zawarta w niej teza o zaostrzającej się „,walce klasowej” usprawiedliwiała zniewolenie. Mao powiada o wojnie klasowej, iż jest ona „najwyższą formą rewolucji” oraz „logiką ludu”: każda myśl, która zachęca do zatrzymania choć na chwilę tej walki, jest błędna ${ }^{18}$. Pomimo reform z 1978 r. Partia nie zrezygnowała z monopolu na środki indoktrynacji. Teoria Deng Xiaopinga określona jest

${ }^{15}$ A. Payette, Institutionalisation of the Party's Leadership Nomination System: The "Path” to the Top in Communist China, „International Journal of China Studies” 6(3)/2015, ss. 231-272.

${ }^{16}$ J. Rowiński, W. Jakóbiec, System konstytucyjny Chińskiej Republiki Ludowej, Wyd. Sejmowe, Warszawa 2006.

17 J. Polit, Chiny, Trio, Warszawa 2004.

${ }^{18}$ Mao Zedong, Mao Zhuxi yanlu, Xinhua Shudian, Huhehaote 1967, ss. 121, 135, 139. 
w nowelizacji konstytucji z 1999 r. jako oficjalny „ideologiczny drogowskaz państwa”. W 2002 r. dołączono do niej zasadę trzech reprezentacji (三个 代表, Sāngè Dàibiǎo). Grupy, które nie chcą uznać ideologicznego monopolu Partii, schodzą do podziemia bądź są prześladowane. I tak, w kościele państwowym znajduje się jedynie 200 tys. Chińczyków, podczas gdy poza nim sytuuje się $67 \mathrm{mln}$ chrześcijan, z czego połowa to protestanci ${ }^{19}$. Burzy się nowo budowane kościoły, a chińscy duchowni trafiają do więzień, gdzie są torturowani ${ }^{20}$. Liczba chrześcijan mimo to stale wzrasta - każdego roku pół miliona Chińczyków przyjmuje chrzest w jednym z protestanckich kościołów ${ }^{21}$. Last but not least, Partia intensywnie kontroluje Internet oraz blokuje konkretne portale i strony (np. Google, Facebook).

Nie ulega zatem wątpliwości, że w społeczeństwie chińskim wykształcił się system trój-panowania klasowego. Jest to system trój-panowania w wersji politycznej, gdyż klasa trój-panująca przejmuje kontrolę nad środkami produkcji i indoktrynacji, zaś panowanie w gospodarce i kulturze podporządkowane jest instrumentalnie maksymalizacji regulacji władczej. Zmiany w strukturze klasy właścicieli i klasy kapłanów po reformach Denga nie oznaczały jakiejkolwiek utraty pozycji klasy władców, która jest względem nich zwierzchnia. Począwszy od 1949 r., „państwo to Partia” - w czasie rewolucji kulturalnej było to jedynie lepiej widoczne, lecz nie oznacza, że w jakimkolwiek okresie ChRL Partia zrezygnowała, choćby na chwilę, ze swojego monopolu na środki przymusu, produkcji i indoktrynacji. Reformy gospodarcze ostatnich lat można traktować jako wyłanianie się z klasy trój-panującej klasy właścicieli, jest to jednak proces powolny i w pełni kontrolowany przez władzę.

Pora na zastosowanie aparatury pojęciowej modelu I teorii władzy n-Mmh do analizy dynamiki władzy w powojennych Chinach. Bezpośrednio analizowany okres obejmuje pół wieku (1949-1989). W części tej wyróżnię w ówczesnej historii Chin fazy: postępującej alienacji obywatelskiej, pierwotnej rewolucji politycznej, zniewolenia z subfazą samozniewolenia władzy, cyklicznych deklasacji i cyklicznych rewolucji.

${ }^{19}$ K. Wenzel-Teuber, 2012 Statistical Update on Religions and Churches in the People's Republic of China and in Taiwan, „Religions \& Christianity in Today’s China” III, 3/2013, ss. 18-43.

${ }^{20}$ Por. Raport China Aid za 2014, http://wiadomosci.wp.pl/kat,1356,title,Nasilaja-sieprzesladowania-chrzescijan-w-Chinach,wid,17705562, wiadomosc.html?ticaid=11676d [16.07.2016].

${ }^{21}$ Wang Hongyi, China plans establishment of Christian theology, „China Daily” 7.08.2014. 
Rewolucja komunistyczna, omawiana zwykle w podręcznikach historii pod nazwą „,chińskiej wojny domowej”, wydaje się raczej politycznym konfliktem między dwiema partiami aniżeli rewolucją obywatelską o szerokiej bazie społecznej. W rzeczy samej Kuomintang występował w tej wojnie jako partia rządząca, która miała za sobą dekadę rządów junty wojskowej oraz tragiczną w skutkach wojnę z Japonią. Nędza, do której doprowadziły wydarzenia lat 30. i 40., znacząco zwiększyła poziom alienacji obywatelskiej i to właśnie dzięki poparciu obywateli szala zwycięstwa w wojnie między Kuomintangiem i Partią Komunistyczną przechyliła się na korzyść Mao i towarzyszy. Lung Ying-tai podaje, że w czasie samych walk o Xuzhou komuniści zmobilizowali 5,34 mln chłopów ${ }^{22}$. Obietnica dokonania reformy rolnej przyciągała do KPCh masy bezrolnych chłopów, którzy nie mieli nic do stracenia - to przede wszystkim z ich punktu widzenia wojna 1945-1949 miała wymiar rewolucyjny. Kuomintang, zamiast pójść na ustępstwa wobec niesprzymierzonej z komunistami ludności miejskiej, zaczął przejmować banki i fabryki (w kilka lat po tym, jak to samo czynili Japończycy) oraz rekwirować zaopatrzenie ludności cywilnej na poczet walki z komunistami. Prowadziło to do strajków wśród studentów i inteligencji oraz masowych dezercji w wojsku KMT ${ }^{23}$. Odpowiada to fazie postępującej alienacji obywatelskiej. Wzrost regulacji władczej nie prowadził do wybuchu pierwotnej rewolucji obywatelskiej, gdyż władza - w zamian za przeprowadzenie reformy rolnej - zyskała poparcie chłopstwa, najliczniejszej grupy społecznej w społeczeństwie chińskim² ${ }^{24}$. W jej efekcie partia komunistyczna staje się rdzeniem nowej władzy. Już w 1949 r., a więc po proklamacji Chińskiej Republiki Ludowej, utworzona zostaje Ludowa Polityczna Rada Konsultatywna z Zhou Enlaiem na czele.

Przejawem wzrostu kontroli politycznej była realizacja pierwszego planu pięcioletniego oraz przeprowadzenie reformy rolnej (1950-1953), która swoim przebiegiem daleko wykraczała poza proces parcelacji ziem, będąc pretekstem do zastosowania represji i terroru:

${ }^{22}$ Lung Ying-tai, Dajiang Dahai 1949, Commonwealth Publishing Press, Taipei 2009, s. 184.

${ }^{23}$ E.P. Leung (red.), Historical Dictionary of Revolutionary China, 1839-1976, Greenwood Publishing Group, Westport 1996, s. 96.

${ }^{24}$ Być może - gdyby wprowadzić do modelu wymiar ekonomiczny życia społecznego - dałoby się to wyjaśnić tzw. efektem NEP-u: zaspokojenie ekonomicznych aspiracji chłopstwa przyczyniało się do wzrostu poparcia władzy, a na pewno stabilizowało jej panowanie. Zob. L. Nowak, U podstaw teorii socjalizmu, t. 3: Dynamika władzy, Nakom, Poznań 1991, ss. 227-229. 
Na początku niewielka grupa kadry sprawdzała, kto jest największym „wrogiem ludu” [...]. Następnie zbierali oni mieszkańców i podczas „wieców walki” zachęcali ich, by donieśli na tych, którzy ich prześladowali. Gdy mieszkańcy byli już dostatecznie podburzeni, sprowadzano co poniektórych bogatych chłopów lub chciwych obszarników, doprowadzano ich przed Sąd Ludowy, oskarżano i skazywano na śmierć (egzekucja była publiczna, a obecność mieszkańców obowiązkowa) lub na reedukację przez pracę ${ }^{25}$.

W wyniku tego typu egzekucji oraz pokazowych procesów związanych z wywłaszczaniem życie straciło kilka milionów ludzi ${ }^{26}$. Powstanie komun stanowiło okazję do rekrutacji spośród ludności wiejskiej osób do klasy trój-panującej, która sprawowała (momentami bezgraniczną) władzę nad pracującymi w komunie rolnikami. W rezultacie swoboda chińskiego rolnika została jeszcze bardziej ograniczona niż w czasach feudalizmu - nałożone zostały na niego obowiązki wynikające z bycia członkiem zespołu produkcyjnego, brygady i wreszcie jednej z 70 tys. komun ${ }^{27}$. Wielopoziomowy system opodatkowania chłopa sprawiał, iż racja zboża, którą mógł spożyć sam chłop, była bardzo niska, znacznie niższa niż uznawana za wystarczającą dla jednej osoby dzienna dawka 1700 kalorii ${ }^{28}$. Deklasacja ta była tym dotkliwsza, że to właśnie małorolni chłopi wspierali rewolucję komunistyczną i byli współodpowiedzialni za jej zwycięstwo.

Partia obejmowała swoją kontrolą kolejne grupy społeczne. Tak zwana kampania stu kwiatów, prowadzona pod hasłem „niech współzawodniczy sto szkół myśli”, miała zjednać inteligencję poprzez zachętę do wysunięcia krytycznych opinii (提意见, tí yìjiàn), doprowadziła jednak do zmasowanej krytyki KPCh i postulatów demokratyzacji polityki. Klasa władców, dostrzegając, że nastąpiło zbyt duże rozluźnienie sfery regulacji, rozpoczęła kampanię przeciw prawicowcom, w trakcie której zginęło około pół miliona Chińczyków ${ }^{29}$. Około 700 tys. wykształconych Chińczyków zostało odsuniętych od stanowisk, większość z nich skierowano do reedukacyjnych obozów pracy na wsiach. Po dziesięciu latach rządów komunistów w pań-

${ }^{25}$ W.S. Morton, C.M. Lewis, Chiny. Historia i kultura, tłum. B. Zemanek, Wyd. Uniwersytetu Jagiellońskiego, Kraków 2007, ss. 236-237.

${ }^{26}$ J.K. Fairbank, M. Goldman, China. A New History, The Belknap Press of Harvard University Press, Cambridge - London 2006, s. 350. Dokładna liczba jest trudna do oszacowania.

${ }^{27}$ J. Oi, State and the Peasant in Contemporary China, University of California Press, Berkeley 1989, s. 5.

${ }^{28}$ J.K. Fairbank, M. Goldman, China..., s. 356.

${ }^{29}$ J. Prybyla, The Hundred Flowers of Discontent, „Current History” 476/1981, ss. 254-259. 
stwie liczącym pół miliarda ludzi było zaledwie 200 tys. absolwentów szkół wyższych, głównie politechnik ${ }^{30}$.

Zainaugurowana w latach 1957-1958 polityka „wielkiego skoku”, choć oficjalnie przedstawiana jako próba nagłego ożywienia chińskiej gospodarki, umożliwiała wzrost regulacji władczej w kolejnych sferach życia społecznego. Wraz z rozpoczęciem kampanii ustanowiono oddziały milicji ludowej, które miały dokonać militaryzacji codziennego życia Chińczyków. W ciągu roku ruch ten objął $300 \mathrm{mln}$ obywateli, tj. prawie połowę populacji ${ }^{31}$. W dziele budowy chińskiego przemysłu zmobilizowano wszystkich obywateli (650 $\mathrm{mln}$ ), a $100 \mathrm{mln}$ do samej produkcji stali ${ }^{32}$. Przetapianie złomu oraz produkcja stali w prymitywnych dymarkach zrujnowały przemysł, a postępująca kolektywizacja wraz z klęskami żywiołowymi doprowadziła do wielkiego głodu. Klęska głodu pochłonęła co najmniej $30 \mathrm{mln}$ istnień. Odnotowywano również przypadki kanibalizmu ${ }^{33}$. Życie tych, którzy przeżyli, podlegało radykalnej kontroli - za całkowitym zakazem jakiejkolwiek własności prywatnej poszła skrajna organizacja życia ludności wiejskiej w komunach: kobiety i mężczyźni mieszkali w osobnych dormitoriach i mogli spotykać się tylko w określonym czasie ${ }^{34}$. Zgodnie z modelem I teorii władzy w n-Mmh odpowiednikiem okresu określanego w historiografii chińskiej jako „dwadzieścia straconych lat” (1955-1975) jest faza zniewolenia politycznego.

Warto zauważyć, że zgodnie z modelem władzy w n-Mmh w fazie zniewolenia rośnie „agresywność” klasy władców, tj. dążenie do poszerzenia sfery regulacji władczej na obywateli innych państw. I rzeczywiście, można odnotować tendencje wzrostu zewnętrznej agresywności bez wchodzenia w szczegółową prezentację. Przykładowo w 1949 r. ChRL włącza się w wojnę w Korei, którą propaganda przedstawiła jako wspaniałe zwycięstwo Chin nad burżuazyjnymi Stanami Zjednoczonymi (w rzeczywistości podpisano rozejm). W tym samym roku ChRL dokonuje „wyzwolenia” Tybetu. W 1958 r. ChRL przystępuje do ataku na Tajwan, który to konflikt kończy się wobec szybkiej reakcji USA i wycofania poparcia ze strony ZSRR. W 1962 r. w wyniku wojny chińsko-indyjskiej zajęto terytorium Aksai Chin. W latach 60. i 70. mamy zatem do czynienia z intensyfikacją znie-

30 J.K. Fairbank, M. Goldman, China..., ss. 363-365.

${ }^{31}$ L. Lüthi, Chiny - ZSRR. Zimna wojna w świecie komunistycznym, tłum. J. Pawłowski, K. Urban-Pawłowska, Wyd. Akademickie Dialog, Warszawa 2011, s. 115.

32 J.K. Fairbank, M. Goldman, China..., s. 371.

33 S. Vardy, A. Vardy, Cannibalism in Stalin's Russia and Mao’s China, „East European Quarterly” 41(2)/2007, ss. 223-38.

${ }^{34}$ W.S. Morton, C.M. Lewis, Chiny..., s. 245. 
wolenia. Wielką Proletariacką Rewolucję Kulturalną lat 1966-1976 można interpretować jako fazę zniewolenia z subfazą samozniewolenia wła dzy. Bezpośrednim impulsem do ogłoszenia rewolucji kulturalnej było dążenie klasy władców, zwłaszcza Mao, do zapobieżenia wydarzeniom, które miały miejsce w ZSRR, czyli postalinowskiemu „rewizjonizmowi”. Jego widmo stanowiło bowiem groźbę znacznego zmniejszenia strefy regulacji władczej Partii. W trakcie eliminacji „elementów burżuazyjnych” do więzień trafiło lub zabitych zostało około 30 mln Chińczyków ${ }^{35}$. Na terenie państwa szerzył się terror, którego dokonywała Czerwona Gwardia (红卫兵, Hóng Wèibīng) - paramilitarna organizacja studentów, która wedle danych współczesnych rządowych historyków liczyła 700 tys. osób ${ }^{36}$. Czerwonogwardziści sami zostali zniewoleni, by stać się narzędziem zniewalania innych. Jak sami bowiem mówili, przewodniczący Mao zdefiniował ich przyszłość, a na drodze do niej nic i nikt ich nie powstrzyma ${ }^{37}$. W ramach kampanii niszczenia „czterech starych” (四旧, sìjiù) hunwejbini atakowali wszystko, cokolwiek wiązało się ze starymi obyczajami, ideami, tradycjami i kulturą. Zniszczono ogromną liczbę zabytków konfucjańskich, buddyjskich i taoistycznych, zdewastowano budowle, cmentarz i posągi, z grobowca dynastii Ming wyciągnięto i sprofanowano nawet zwłoki pary cesarskiej, zniszczono brązy i spalono tradycyjne księgi. W czasie rewolucji kulturalnej zamknięto również wszystkie szkoły, m.in. dlatego żyjące w tych czasach pokolenie młodych ludzi literatura chińska nazywa „straconym pokoleniem”. Produkcja fabryk spadła w tym czasie o około $10 \%$, a w Chinach południowych i wschodnich aż o 40\%. Wielkie fabryki zbudowane w Henanie, Hebei i Hunanie najpierw z racji swojej nierentowności, a następnie najzwyczajniej porzucone, spowodowały straty rzędu 25 mln dolarów ${ }^{38}$.

Jak zauważa John King Fairbank, powszechny terror był możliwy dzięki całkowitej erozji społeczeństwa obywatelskiego oraz bierności i posłuszeństwu Chińczyków wobec autorytarnej władzy. Istotne było również wieloletnie wpajanie obywatelom, że koncepcja praw człowieka jest z gruntu egoistyczna i antysocjalistyczna ${ }^{39}$. Zauważmy, iż właśnie poprzez

${ }^{35}$ A. Walder, Yang Su, The Cultural Revolution in the Countryside: Scope, Timing and Human Impact, „The China Quarterly” 173/2003, ss. 74-99.

${ }^{36}$ Ni Tianzui, Mao zhuxi ba ci jiejian hongweibing de zuzhi gongzuo, http://dangshi. people.com.cn/GB/85039/14329784.html [16.07.2016].

${ }^{37}$ W.L. Chong, China's great proletarian Cultural Revolution: master narratives and post-Mao counternarratives, Rowman \& Littlefield, Lanham 2002, s. 105.

${ }^{38}$ Liang Bai, Economic Legacies of the Cultural Revolution, „Job Market Paper” 14.01.2014, s. 12 .

39 J.K. Fairbank, M. Goldman, China..., s. 383. 
redukcję społeczeństwa obywatelskiego oraz szerzenie się postaw zniewolenia i braku oporu definiuje się w n-Mmh zniewolenie. Odpowiednikiem subfazy samozniewolenia władzy jest okres rewolucji kulturalnej, w którym doszło do represji członków klasy władców. W 1966 r. Mao wydał okólnik informujący o „przedstawicielach burżuazji, którzy wdarli się do Partii”. Liu Shaoqi, głowa państwa, zmarł w 1968 r. w więzieniu; jego następca, Lin Biao, zginął w owianym tajemnicą wypadku lotniczym na terenie Mongolii; odsunięto od władzy generałów - przywódców Wielkiego Marszu: Penga Duhaia i Zhu De, również Deng Xiaoping, wówczas sekretarz generalny partii, był represjonowany. W czasie rewolucji kulturalnej czystki objęły około 60\% wszystkich członków Partii, 400 tys. członków Partii poniosło śmierć, a 700 tys. trafiło do więzień, skazanych w pokazowych i bezprawnych procesach ${ }^{40}$.

W drugiej połowie 1968 r. ofiarą czystek padła sama Czerwona Gwardia, której funkcjonariusze ją wcześniej zainicjowali. Za sprawą armii wysłano na wieś od 12 do 20 mln czerwonogwardzistów, 3 mln zostało aresztowanych, a na kilku milionach dokonano egzekucji ${ }^{41}$. Porażka Czerwonej Gwardii oznaczała kres kariery Mao jako Pierwszego Sternika:

Nadal okazywano wierność przywódcy, ale społeczeństwo powoli się budziło, aż w końcu w latach 1976-1979 nastąpił wybuch [...]. Kiedy we wrześniu 1976 roku terror osłabł, Mao był już od jakiegoś czasu praktycznie martwy (przynajmniej politycznie). Dowodzi tego zarówno brak większej, spontanicznej reakcji na wiadomość o jego zgonie, jak i to, że nie potrafił znaleźć następcy ${ }^{42}$.

Nie śmierć jednostki, a wewnętrzna dynamika władzy stanowiły bezpośredni powód przemian politycznych 1976 r. Reformy Denga Xiaopinga obejmujące m.in. powołanie stref ekonomicznych dla zachodniego kapitału, liberalizację działalności sektora prywatnego i likwidację systemu komun ludowych na wsiach można interpretować w kategoriach ustępstw chińskiej klasy trój-panującej. Osobliwością przejścia do fazy cyklicznych deklasacji w przypadku chińskim jest brak poprzedzających koncesje wystąpień rewolucyjnych. W świetle teorii władzy w n-Mmh niski poziom oporu społecznego wyjaśniany jest albo niskim, albo ekstremalnie wysokim bo rozbijającym więzi międzyludzkie - poziomem zniewolenia. Wydaje

40 Ibidem, s. 387.

41 J.-L. Margolin, Chiny - długi marsz w ciemności, w: S. Courtiois i in. (red.), Czarna księga komunizmu, Prószyński i S-ka, Warszawa 1999, ss. 504-505.

${ }^{42}$ Ibidem, ss. 505-506. 
się, że w przypadku chińskim mamy do czynienia z drugą sytuacją. Warto zwrócić uwagę, że koncesje w społeczeństwie chińskim miały charakter nie polityczny, a ekonomiczny. Wskutek braku wystąpień rewolucyjnych nie doprowadziły one do naruszenia partyjnego monopolu na władzę, przyczyniły się natomiast do rozpoczęcia procesu stopniowego wyłaniania się osobnej klasy właścicieli. Dekadę później nowelizacja konstytucji ChRL z 12 kwietnia 1988 r. usankcjonowała ten stan rzeczy, uznając sektor prywatny za „uzupełnienie” gospodarki socjalistycznej, oraz dopuściła możliwość obrotu prawem użytkowania gruntów.

Kierunek tych przemian nie powinien nas jednak zmylić. Przypomnijmy, że w fazie cyklicznych deklasacji występuje następujący wzorzec rozwojowy: „rewolucja - ustępstwa - etatyzacja - rewolucja etc.”. Oznaki żądań liberalizacji i demokratyzacji pojawiły się w społeczeństwie chińskim dość szybko: już w 1978 r. Wei Jingsheng przedstawił esej Piq̨a modernizacja, w którym pisał, że Chińczycy potrzebują demokracji i wolności, a nie bycia narzędziem, poprzez które dyktatorzy dokonują modernizacji ${ }^{33}$. Styl rządzenia władz chińskich nie uległ bowiem istotnej zmianie, o czym świadczy choćby radykalność wprowadzania w życie (na początku lat 80.) polityki jednego dziecka: sferze kontroli (a więc i kar) ze strony klasy władców poddano jedną z najbardziej podstawowych sfer życia osobistego. Powiększanie się nierówności społecznych oraz bezradność obywateli (pozbawionych ochrony prawa i świadczeń socjalnych) wobec rozrastającego się systemu korupcyjnych powiązań guanxi umożliwiały wzrost etatyzacji politycznej.

W 1989 r., w trakcie strajków na placu Tian’anmen w Pekinie, grupa 100 tys. obywateli, przeważnie młodych, domagała się tego samego co dysydent Wei: liberalizacji i demokratyzacji życia publicznego w Chinach ${ }^{44}$. Demonstracje te można interpretować jako początek rewolucji obywatelskiej, która miała doprowadzić do ograniczenia sfery regulacji poprzez żądania wycofania się władzy z kontroli polityki, gospodarki i kultury. Bunt ten został brutalnie stłumiony, a rewolucja - jeszcze na dobre nierozpoczęta przegrana. Jak każda przegrana rewolucja, także i ta z 1989 r. przyniosła ustępstwa ze strony władzy, inicjujące drugi cykl fazy cyklicznej deklasacji. Ustępstwa te są jednak stopniowane, co widać choćby na przykładzie stopniowej liberalizacji prawa w zakresie własności prywatnej czy postępującego osłabiania polityki jednego dziecka, zniesionej ostatecznie w 2015 r.

${ }^{43}$ Wei Jingsheng, The Courage to Stand Alone: Letters from Prison and Other Writings, Penguin Books, New York 1997, ss. 208-210. Lata 1979-1997 Wei Jingsheng spędził w więzieniu.

${ }^{44}$ A. Nathan, The Tiananmen Papers, „Foreign Affairs” Jan.-Feb. 2001. 
Od polityki tej z powodzeniem uciekają również komunistyczni oficjele: w latach 2000-2005 w samym Hunanie około 2 tys. urzędników miało więcej niż jedno dziecko ${ }^{45}$. Obietnice wprowadzenia systemu ubezpieczeń społecznych w ramach nowej pięciolatki to kolejne ustępstwa, które mają na celu maksymalne opóźnienie kolejnego buntu i zachowanie autorytarnej władzy KPCh. Chińskie społeczeństwo obywatelskie jest zbyt słabe, a klasa władców zbyt silna, by wystąpiła tu już faza cykliczny ch rewolucji. Nic nie zapowiada również tego, by nastąpiła ona w najbliższej przyszłości. Społeczeństwo chińskie tkwi zatem w drugim cyklu fazy deklasacji. Opisane zależności przedstawia poglądowo poniższy wykres:

Wykres 1. Dynamika władzy w ChRL według faz

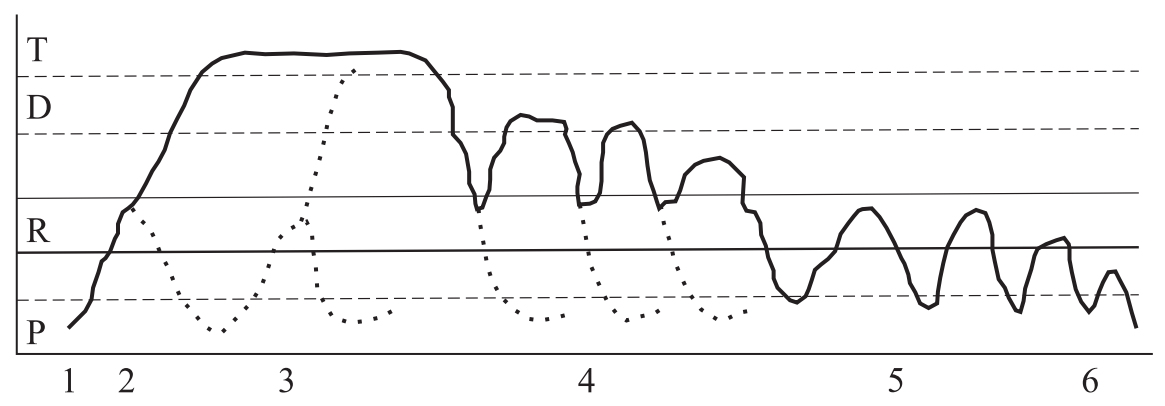

Objaśnienia: $\mathrm{p}$ - próg pokoju klasowego, $\mathrm{R}$ - obszar rewolucji, d - próg deklasacji, $\mathrm{T}$ - próg totalitaryzacji; fazy rozwojowe: 1 - faza postępującej alienacji obywatelskiej, 2 faza pierwotnej rewolucji obywatelskiej, 3 - faza zniewolenia, 4 - faza cyklicznych deklasacji, 5 - faza cyklicznych rewolucji, 6 - faza pokoju klasowego.

Reasumując, w historii społeczeństwa chińskiego można wyróżnić odpowiednik fazy postępującej alienacji obywatelskiej (1945-1949), fazy zniewolenia (1956-1976), sub-fazy zniewolenia władzy (1966-1976) i fazy cyklicznych deklasacji (1976-89 - pierwszy cykl i drugi od 1989). Osobliwością rozwojową tegoż społeczeństwa jest brak wyraźnie odrębnej pierwotnej rewolucji obywatelskiej i rewolucji obywatelskiej inicjującej pierwszy cykl fazy cyklicznej deklasacji. Rewolucja taka zainicjowała natomiast drugi cykl tej fazy w 1989 r. Jak na silne warunki idealizujące model władzy stanowi jednak zadowalające przybliżenie powojennego rozwoju społeczeństwa chińskiego.

${ }^{45}$ Over 1,900 officials breach birth policy in C. China, „Xinhua” z 8.07.2007 r. 


\section{Prognozy i perspektywy}

W ostatniej części chciałbym przedstawić ogólne prognozy czy też zarysować generalne trendy, które inspirowane są sposobem konceptualizacji świata społecznego w nie-Marksowskim materializmie historycznym.

W polityce wewnętrznej można przewidywać stopniowy spadek regulacji władczej, który będzie postępować do progu rewolucji politycznej ${ }^{46}$. Tak długo, jak w społeczeństwie chińskim nie wykształci się silne społeczeństwo obywatelskie, ustępstwa polityczne trój-władzy nie wykroczą zatem poza fazę cyklicznych deklasacji.

Ten spadek regulacji władczej w polityce wewnętrznej rekompensowany będzie wzrostem regulacji władczej w polityce zagranicznej. Dokonywać się to będzie głównie poprzez środki gospodarcze i kulturowe (np. Instytuty Konfucjusza). Ekspansja gospodarcza Chin będzie instrumentalnie podporządkowana powiększaniu zewnętrznej sfery wpływów.

Ustępstwa trój-władzy w sferze gospodarczej, tj. zgoda na działalność kapitału zagranicznego i rodzimych firm oraz indywidualne użytkowanie ziemi przez chłopstwo z jednej strony zapewni wewnętrzną stabilizację panowania trój-władzy, a z drugiej - wzrastająca efektywność chińskiej gospodarki będzie instrumentem zwiększania wpływów na arenie międzynarodowej. Ten rodzaj ekonomicznej dominacji w stosunkach międzyspołecznych będzie wyrażać się w budowie hegemonii ekonomicznej ${ }^{47}$. Ustępstwa gospodarcze doprowadzą do wzrostu zamożności obywateli oraz wyłonienia się odrębnej klasy właścicieli.

W sferze kulturowej dokonywać się będzie dalsze odejście od pozostałości marksizmu-leninizmu, które rozpoczęło się w 1978 r. W celu ideologicznego uzasadnienia pozycji Chin na arenie międzynarodowej w oficjalnym dyskursie coraz częściej pojawiać się będą odwołania do konfucjańskiej i cesarskiej przeszłości ${ }^{48}$. Klasa trój-panująca nie zrezygnuje jednak z monopolu duchowego, tj. nie dopuści do powstania odrębnej klasy

${ }^{46}$ M. Stepan, Two years of refurbishing the command and control apparatus: the Chinese Communist Party strengthens its hold on the judicial system and societal forces, „China Monitor” 28/2015.

${ }^{47}$ K. Brzechczyn, O ścieżkach upadku imperium sowieckiego. Próba typologii w świetle nie-Marksowskiego materializmu historycznego, w: A. Nowak (red.), Ofiary imperium. Imperia jako ofiary. 44 spojrzenia, IPN - IH PAN, Warszawa 2010, ss. 572-574.

48 J. Pawłowski, Przeszłość w ideologii Komunistycznej Partii Chin, Wyd. Uniwersytetu Warszawskiego, Warszawa 2013, ss. 258-289. 
kapłańskiej, gdyż w obliczu przewidywanego przez nas wyodrębnienia się klasy właścicieli skutkowałoby to całkowitą erozją partyjnej trój-władzy. Państwowa cenzura będzie w dalszym ciągu kontrolować kulturalną aktywność obywateli, wykluczając jakikolwiek pluralizm światopoglądowy, który - związany z hasłami demokratyzacji - zagraża klasie władców oraz prowadzi do ograniczenia sfery regulacji władczej ${ }^{49}$.

Konkretne prognozy wynikające z aplikacji n-Mmh świadczą o wspomnianych zaletach metodologicznych tej koncepcji, która w spójny i precyzyjny terminologicznie sposób jest w stanie uchwycić i opisać dynamikę władzy w powojennych Chinach.

Jak już wspomniałem, osobliwością historii Chin z perspektywy n-Mmh jest brak rewolucji inicjującej fazę cyklicznych deklasacji. Wyzwaniem stojącym przed tą teorią jest zatem opracowanie takiej wizji ekspansji Chin, która na równi z czynnikami politycznymi uwzględni czynniki natury ekonomicznej - wymagałoby to jednak dalszej konkretyzacji założonych modeli. Odrębnym wyzwaniem badawczym byłaby również adaptacja kolejnych modeli oraz poszerzenie zakresu adaptacji modeli I-II (np. dla wspomnianego okresu 1912-1949). Możliwość rozwoju tej koncepcji, przy potwierdzonej już mocy eksplanacyjnej i prognostycznej, powinna stanowić zachętę do jej dalszej rozbudowy oraz powszechniejszej aplikacji.

\section{Literatura}

Avanzini F., Religie Chin, tłum. K. Stopa, WAM, Kraków 2004.

Bell D., China's New Confucianism: Politics and Everyday Life in Changing Society, Princeton University Press, Princeton 2010.

Bręgiel-Benedyk M., Obraz struktury społecznej w Manusmryti. Próba analizy teoretycznej, „Poznańskie Studia z Filozofii Humanistyki” t. 22: Jednostka w układzie społecznym. Próba teoretycznej konceptualizacji, red. K. Brzechczyn, M. Ciesielski, E. Karczyńska, Wyd. Naukowe WNS UAM, Poznań 2013.

Brzechczyn K., O ścieżkach upadku imperium sowieckiego. Próba typologii w świetle nie-Marksowskiego materializmu historycznego, w: A. Nowak (red.), Ofiary imperium. Imperia jako ofiary. 44 spojrzenia, IPN-IH PAN, Warszawa 2010.

Brzechczyn K., O wielości linii rozwojowych w procesie historycznym. Próba interpretacji ewolucji społeczeństwa meksykańskiego, Wyd. Naukowe UAM, Poznań 2004.

${ }^{49}$ W 2013 r., w odpowiedzi na przemówienie Xi Jinpinga o „chińskim marzeniu”, pojawiło się wiele artykułów wzywających do zbudowania demokratycznych i konstytucjonalnych Chin. Teksty te wskutek cenzury nie ujrzały jednak światła dziennego, czemu towarzyszyły protesty. Por. M. Stępień, Chińskie marzenie o konstytucjonalizmie, Wyd. Uniwersytetu Jagiellońskiego, Kraków 2015, ss. 143-147. 
Brzechczyn K., Zapaść obywatelska i absorpcja elit. Próba poszerzenia teorii ewolucji społeczeństwa politycznego, „Poznańskie Studia z Filozofii Humanistyki” t. 17: Marksizm, liberalizm, próby wyjścia, red. L. Nowak, P. Przybysz, Zysk i S-ka, Poznań 1997.

Chong W.L., China's great proletarian Cultural Revolution: master narratives and post-Mao counternarratives, Rowman \& Littlefield, Lanham 2002.

Ciesielski M., Problem kumulacji podziałów klasowych we współczesnym kapitalizmie, „Poznańskie Studia z Filozofii Humanistyki” t. 22: Jednostka w układzie społecznym. Próba teoretycznej konceptualizacji, red. K. Brzechczyn, M. Ciesielski, E. Karczyńska, Wyd. Naukowe WNS UAM, Poznań 2013.

Czajkowski W., Kilka uwag o Leszka Nowaka nie-Marksowskim materializmie historycznym oraz Immanuela Wallersteina i Andre G. Franka teoriach systemu światowego, „Poznańskie Studia z Filozofii Humanistyki” t. 22: Jednostka w układzie społecznym. Próba teoretycznej konceptualizacji, red. K. Brzechczyn, M. Ciesielski, E. Karczyńska, Wyd. Naukowe WNS UAM, Poznań 2013.

Karczyńska E., Struktura społeczna Imperium Osmańskiego. Próba analizy teoretycznej, „Poznańskie Studia z Filozofii Humanistyki” t. 22: Jednostka w układzie społecznym. Próba teoretycznej konceptualizacji, red. K. Brzechczyn, M. Ciesielski, E. Karczyńska, Wyd. Naukowe WNS UAM, Poznań 2013.

Fairbank J.K., Goldman M., China. A New History, The Belknap Press of Harvard University Press, Cambridge - London 2006.

Leung E.P. (red.), Historical Dictionary of Revolutionary China, 1839-1976, Greenwood Publishing Group, Westport 1996.

Liang Bai, Economic Legacies of the Cultural Revolution, „Job Market Paper” z 14.01.2014 r.

Lung Ying-tai, Dajiang Dahai 1949, Commonwealth Publishing Press, Taipei 2009.

Lüthi L., Chiny - ZSRR. Zimna wojna w świecie komunistycznym, tłum. J. Pawłowski, K. Urban-Pawłowska, Wydawnictwo Akademickie Dialog, Warszawa 2011.

Makeham J., New Confucianism. A Critical Examination, Palgrave MacMillan, New York 2003.

Mao Zedong, Mao Zhuxi yanlu, Xinhua Shudian, Huhehaote 1967.

Margolin J.-L., Chiny - długi marsz w ciemności, w: S. Courtiois i in. (red.), Czarna księga komunizmu, Prószyński i S-ka, Warszawa 1999.

Morton W.S., Lewis C.M., Chiny. Historia i kultura, tłum. B. Zemanek, Wyd. Uniwersytetu Jagiellońskiego, Kraków 2007.

Nathan A., The Tiananmen Papers, „Foreign Affairs” Jan.-Feb. 2001.

Nowak L., U podstaw teorii socjalizmu, t. 1-3, Nakom, Poznań 1991.

Oi J., State and the Peasant in Contemporary China, University of California Press, Berkeley 1989.

Over 1,900 officials breach birth policy in C. China, „Xinhua” z 8.07.2007 r.

Pawłowski J., Przeszłość w ideologii Komunistycznej Partii Chin, Wyd. Uniwersytetu Warszawskiego, Warszawa 2013.

Payette A., Institutionalisation of the Party's Leadership Nomination System: The „Path” to the Top in Communist China, „International Journal of China Studies” 6(3)/2015.

Polit J., Chiny, Trio, Warszawa 2004.

Prybyla J., The Hundred Flowers of Discontent, „Current History” 476/1981.

Rowiński J., Jakóbiec W., System konstytucyjny Chińskiej Republiki Ludowej, Wyd. Sejmowe, Warszawa 2006. 
Stepan M., Two years of refurbishing the command and control apparatus: the Chinese Communist Party strengthens its hold on the judicial system and societal forces, „China Monitor” 28/2015.

Stępień M., Chińskie marzenie o konstytucjonalizmie, Wyd. Uniwersytetu Jagiellońskiego, Kraków 2015.

Vardy S., Vardy A., Cannibalism in Stalin’s Russia and Mao's China, „East European Quarterly" 41(2)/2007.

Walder A., Yang Su, The Cultural Revolution in the Countryside: Scope, Timing and Human Impact, „The China Quarterly” 173/2003.

Wang Hongyi, China plans establishment of Christian theology, „China Daily” z 7.08.2014 r.

Wei Jingsheng, The Courage to Stand Alone: Letters from Prison and Other Writings, Penguin Books, New York 1997.

Wenzel-Teuber K., 2012 Statistical Update on Religions and Churches in the People's Republic of China and in Taiwan, „Religions \& Christianity in Today's China” 3/2013.

Zarębski T., Problem totalitaryzacji kapitalizmu, „Poznańskie Studia z Filozofii Humanistyki” t. 19: Ścieżki transformacji. Ujęcia teoretyczne i opisy empiryczne, red. K. Brzechczyn, Zysk i S-ka, Poznań 2003.

Zarębski T., Struktura klasowa społeczeństw hydraulicznych. Próba parafrazy teorii Karla Augusta Wittfogla w aparaturze pojęciowej nie-Marksowskiego materializmu historycznego, „Poznańskie Studia z Filozofii Humanistyki” t. 22: Jednostka w układzie społecznym. Próba teoretycznej konceptualizacji, red. K. Brzechczyn, M. Ciesielski, E. Karczyńska, Wyd. Naukowe WNS UAM, Poznań 2013.

\section{Źródła internetowe}

Laogai Research Foundation, www.laogai.org [16.07.2016].

Ni Tianzui, Mao zhuxi ba ci jiejian hongweibing de zuzhi gongzuo, http://dangshi.people. com.cn/GB/85039/14329784.html [16.07.2016].

Raport China Aid za 2014, http://wiadomosci.wp.pl/kat,1356,title,Nasilaja-sieprzesladowaniachrzescijan-w-Chinach,wid,17705562,wiadomosc.html?ticaid=11676d [16.07.2016]. 
